\title{
Turning Point at the UNESCO Headquarters Crossed Influences Between Pier Luigi Nervi and Marcel Lajos Breuer
}

\author{
Martín Fuentes, Javier \\ BAU International Berlin University of Applied Sciences. martin@bauinternational-berlin.de
}

https://doi.org/10.4995/CIAB8.2018.7424

\begin{abstract}
The history of architecture is closely linked to the evolution and the use of materials. Concrete was the most important material of the 20th century, becoming the medium for a new architecture. Many different architects not only relied on the use of concrete as their main mode of expression but also got involved in the quest for a new architectural language for the so-called new material. Pier Luigi Nervi and Marcel Breuer are not only among the great architects of the last century, but above all, they are masters of concrete, both developing extensive bodies of work based on the use of the material.
\end{abstract}

Nervi and Breuer worked together in a virtuosic piece of architecture, the building for the UNESCO Headquarters in Paris. Built mainly in concrete and inaugurated in 1958, it occupies a relevant place in the history of architecture. This paper wants to highlight how during that process, both architects underwent a radical change in their careers and in relation to the use of concrete, turning this project in a milestone for the history of concrete and therefore for the history of architecture as a whole.

Palabras Clave: Pier Luigi Nervi; Marcel Breuer; UNESCO Headquarters; Turning point; Reinforced concrete.

\section{Two men and one destiny}

The architect Marcel Breuer, born in Hungary in 1902, died as an American citizen in 1981. Having been trained at the Bauhaus in Weimar under the long-lasting patronage of Walter Gropius, he immigrated to the United States in 1937 due to World War II, after spending three years working in England. In the United States, he first lived in Cambridge, Massachusetts, where he taught at the Graduate School of Design (GSD) at Harvard University from 1938 to 1946 . He was at the GSD not by chance, but because at the time, the Department of Architecture was directed by Gropius. Breuer not only taught at the GSD, but he also shared a practice with his mentor for several years. Later, he became independent and moved to New York City, where he started a very successful practice that developed remarkable projects even after his death.

At the Loeb Library, the fascinating archive of the GSD in Cambridge, there is a special collection comprised of 17 folders with lectures and writings by Marcel Breuer, both in manuscript and/or typescript form ${ }^{1}$. Among these files, there is one -AA017- containing some comments about another great architect of the $20^{\text {th }}$ century, Pier Luigi Nervi. In some handwritten lines, Marcel Breuer 


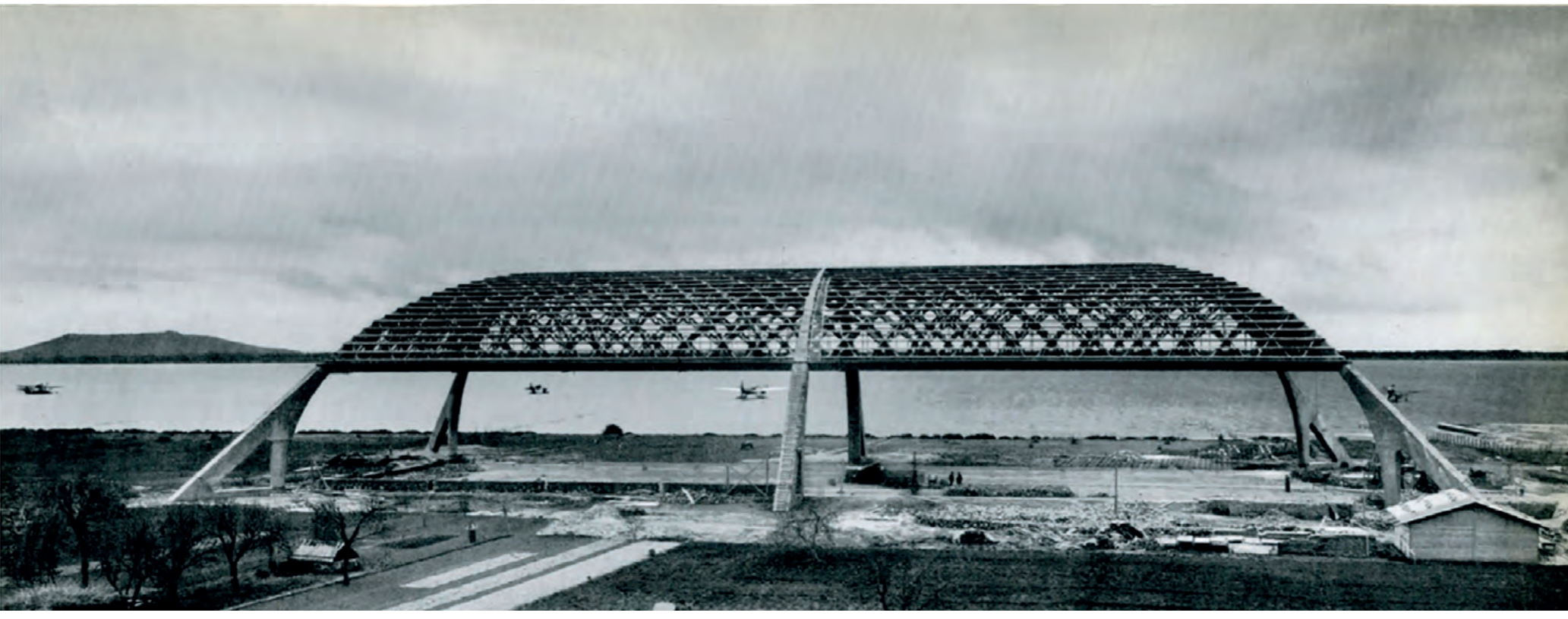

Figure 1. Aircraft Hangars in Orvieto, Italy. Pier Luigi Nervi, 1938-1940. Studio Vasari.

praises his Italian colleague ${ }^{2}$, and not merely out of politeness or correctness, but from the first-hand experience he gained working together with Nervi. Both architects worked together for the first time on the building for the UNESCO Headquarters in Paris, inaugurated in 1958. During this collaboration both architects gained deep reciprocal admiration, as much as they learned from each other. Even more important than cultivating their mutual influence, however, the UNESCO building served as a turning point in their careers.

\section{Pier Luigi Nervi, a master of concrete}

Pier Luigi Nervi was born in 1891 in Sondrio, Italy; and although he graduated from the University of Bologna in 1913 with a degree in engineering rather than architecture, he can still be described as one of the most relevant architects of the $20^{\text {th }}$ century (Herman 1959, 109-110). His entire career was closely linked to one material - concrete - with which he designed numerous structures and developed a series of construction patents. In particular, one main characteristic of Nervi's work is his predilection for prefabricated concrete elements. These ready-made elements were used either as structural components or as a lost formwork.

As an example, in one of his first works, the Orvieto Hangars (19381940) (Fig. 1), the connection pieces for the grid of beams were prefabricated nodes. This was a very experimental type of construction, and Nervi's main concern was the stiffness of the connection, as the steel rods had to be welded on-site. After the destruction of the hangars during WWII, Nervi himself confirmed how strong these connecting components had been: Amid the wreckage, it was possible to see that the structure had broken down in areas in between the connection nodes, which still remained intact (Nervi 1956, 32). Nervi was a pioneer and was never afraid of experimenting and trying new structural solutions, which in most cases ended up being very successful.

Another example of his multiple discoveries was his prefabricated Ferro-cemento formwork. Ferro-cemento is a reinforced concrete material he developed, in which very thin steel meshes are covered with concrete.

Experiments with this material demonstrated immediately its most important and fruitful properties: it could withstand great strains without formation of cracks in the cement mortar, as a result of the subdivision of the reinforcement, and it eliminated forms, because the mortar could be applied directly to the mesh, which would act as a lath to retain it. (Nervi 1956, 18)

He used Ferro-cemento precast formwork for many of his most famous projects. The corrugated roof of the Exhibition Hall in Turin (1948-49) is built with multiple interlocked pieces, whereas for the Pallazeto dello Sport in Rome (1957), Nervi used his recognizable diamond-shape caisson lost-formwork system. Nervi considered concrete the new material of his present time, and therefore maintained that it should be understood and used as such. His work was based on the quest for a new, never-before-used geometry, which 


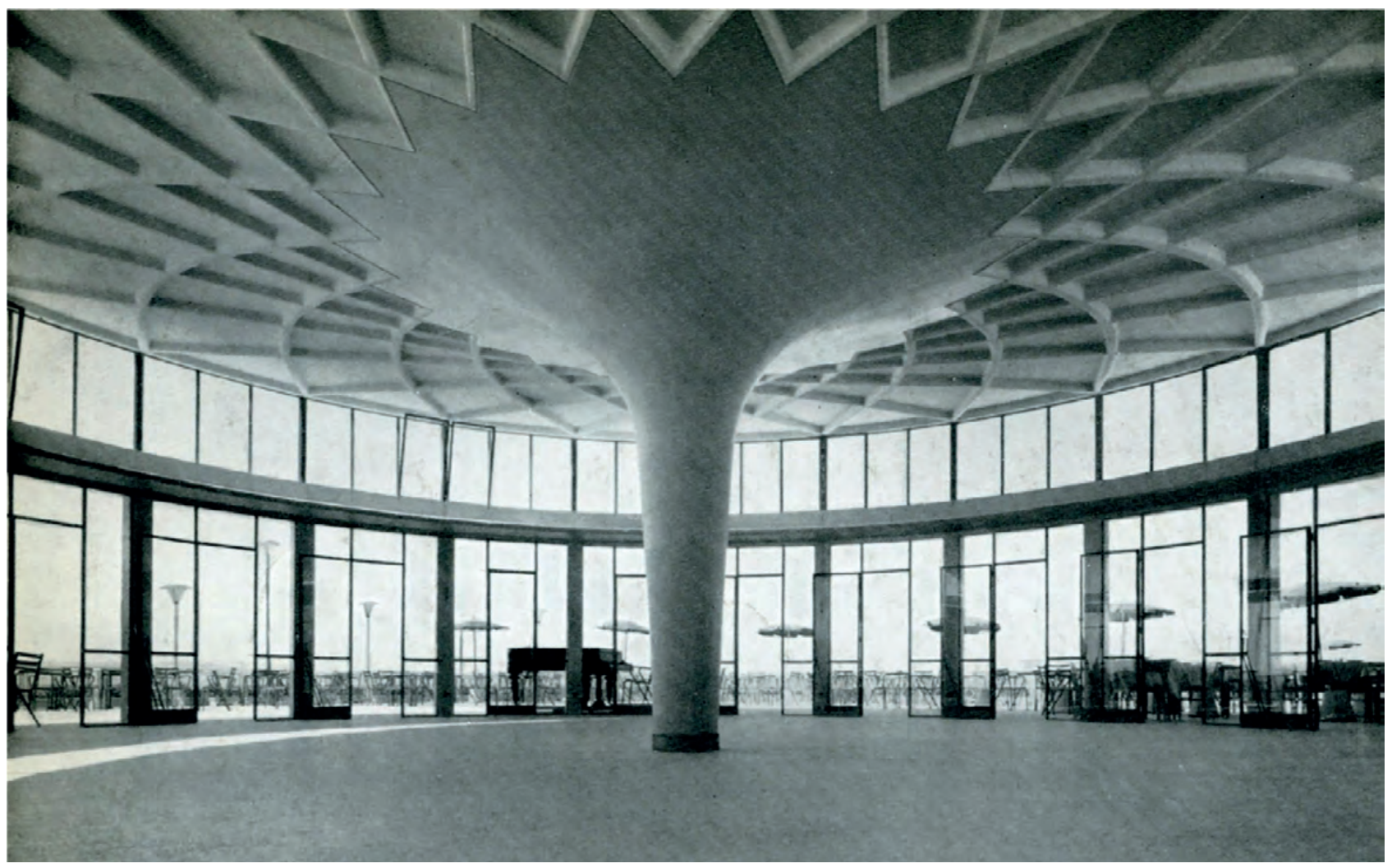

Figure. 2 Kursaal Casino restaurant, Ostia. P.L. Nervi. 1950. Studio Vasari

could fit with the possibilities that concrete offered. As Joseph Abram states, Nervi eliminated every historical filter to place himself in a radically new situation with respect to the material (Abram 2010, 41-57).

In reinforced concrete the most elementary structural elements acquire new and expressive architectural interest. Beams lose the prismatic rigidity of wooden struts and standard metal sections, and may plastically follow the variation of stress. Columns rigidly connected to horizontal elements free themselves from the constant cross-section of stone and masonry pillars. Three dimensional structures like domes and barrels acquire a freedom of form unknown to masonry equilibrium through compressive stresses. (Nervi 1956, 54)

In terms of historical position, Pier Luigi Nervi could be compared to the Swiss civil engineer Robert Maillart, as both remained faithful to reinforced concrete as their main construction material (Fernández Ordóñez 1978, 12). However, while Maillart's conception of structures was based in a game of free planes for spatial articulation, most of Nervi's work gravitates around the problem of the roof, or the definition of the spatial boundary (Argan 1955, 18). This simplic- ity was criticized by the French architect Robert Le Ricolais, who liked to say that Nervi merely made "nice hats," distorting some words Nervi had written about the beauty of structures (Le Ricolais 1962, 151).

Indeed, as this quotation implies, many of Nervi's buildings do have dome- or vault-like shapes, structures that work only under compression, which may seem to contradict the pursuit of a new structural expression with the new material of the century. Yet the domes and barrels Nervi designed and built were more intricate, light and expressive than any gothic structure; reinforced concrete facilitated not only a new structural formal expression, but also more structural capabilities. Reinforced concrete can work both in tension and compression, and therefore the new structural language of the material should be not only expressive, but subjected to flexion.

The driving impulse for Nervi's designs can be found in his concern about material optimization. Nervi focused on the definition of enclosures in the most structurally efficient way, enclosing the space by stretching the roof and making it touch the ground (hence the vaults and domes). In other cases, like the Casino in Ostia (Fig. 2), or the Palazo del Laboro in Turin, he simply erected a system of freestanding columns that support slabs, enclosing the space with 


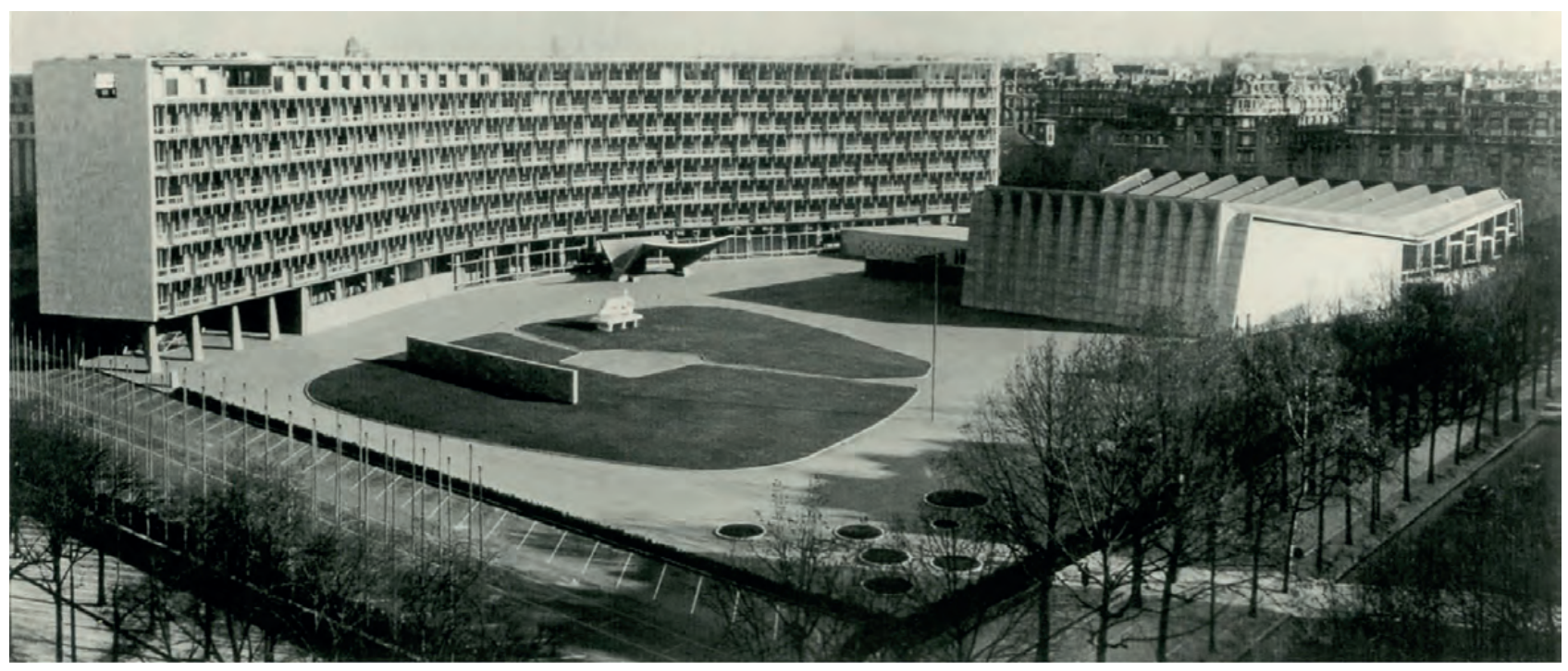

Figure 3. Exterior view of the UNESCO Headquarters complex. P.L Nervi, M. Breuer and B. Zehrfuss. 1955-58. Lee Ewings.

a rather simple façade of glass. For Nervi, the vertical plane had no architectural relevance at all, and architecture was always oriented towards the simplest constructive shape-the one that represents the graphic purity of the project and has as its aim the designation of limits providing protection from the sun and the rain, the architecture of the roof.

\section{Nervi and Breuer at the UNESCO building in Paris}

In 1952, Pier Luigi Nervi started working on one of his most remarkable buildings, the UNESCO Headquarters in Paris. Nervi was included in that project, together with two other architects, for multiple reasons. The first could be the notability he had starting to gain, mainly because of the completion of the Turin Exhibition Complex. The second could be his extended experience in collaborative work, thanks to his twofold role as engineer and architect, which was perfect for the project in Paris. The third can be found in the participation of another Italian architect, Ernesto Rogers, in the committee of experts choosing the architects for the work. Together with Rogers, the committee was composed of a group of renowned architects: Le Corbusier (France), Sven Markelius (Sweden), Lucio Costa (Brazil) and, as the chair of the committee, Walter Gropius (United States) (UNESCO n.d.). Among these names we may find a fourth reason for the choice: Le Corbusier and his predilection for concrete, mastery over which Nervi had already shown.

The other two architects appointed for the project were the French Bernhard Zehrfuss, whose main value to the project probably was that he was a local, and finally Marcel Breuer, whose election is no surprise, considering that his mentor and good friend Gropius headed the commission of experts. The chosen trio started working from

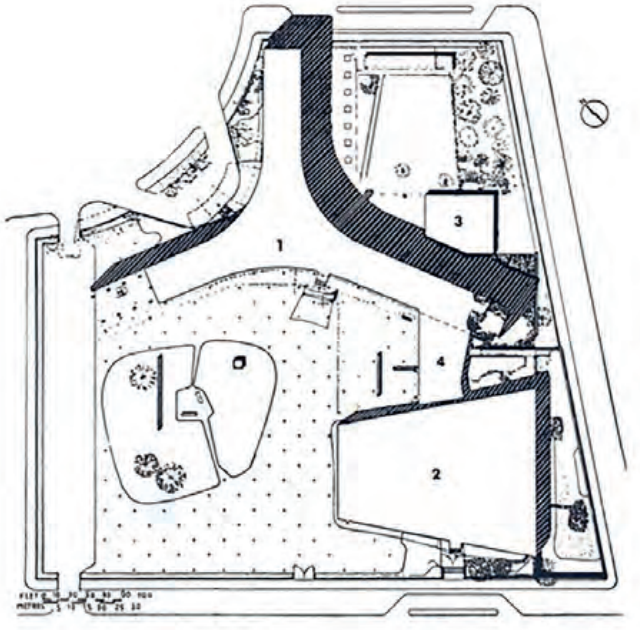

Figure 4. Site Plan UNESCO Headquarters. P.L Nervi, M. Breuer and B. Zehrfuss . 195558. Françoise Choay. Das Unesco-Gebäude in Paris, Stuttgart, p.14.

their respective cities until they finally met in Paris. Despite the distance and possible organizational problems, the division of tasks and the collaborative work was very successful. As Breuer wrote in 1959:

Although each of us had a precisely defined personal task area, there was a constant, intensive exchange of ideas and concepts between the three of us; this was an entirely natural, friendly and down-to-earth process. (Breuer and Jones 1962, 253)

The central administration complex of UNESCO, sited in the $7^{\text {th }}$ arrondissement of Paris, consisted of four buildings (Figs. 3 and 4). 


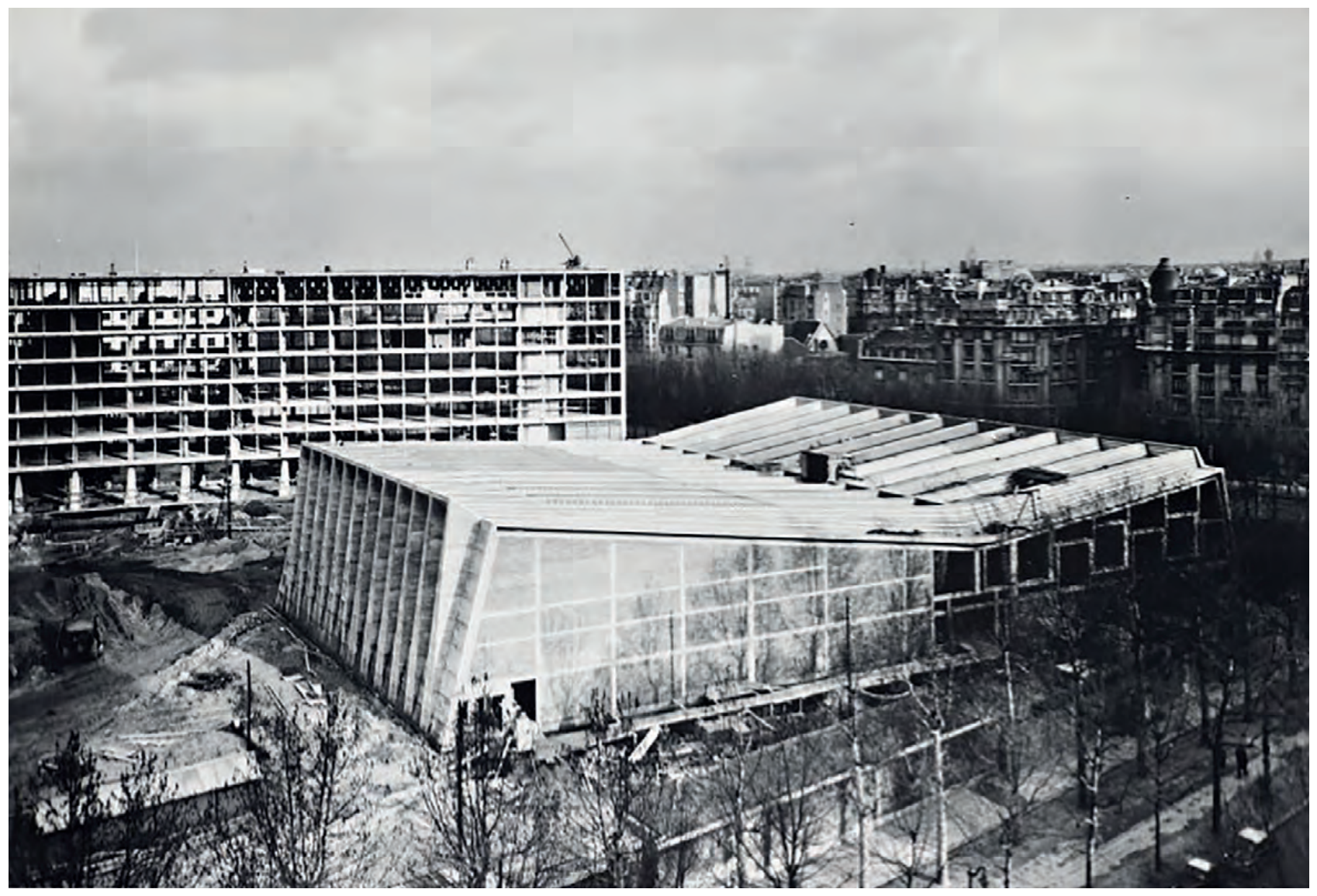

Figure 5. Exterior view of the Conference Hall, UNESCO Headquarters. P.L Nervi, M. Breuer and B. Zehrfuss. 1955-58. L. Hervé.

The largest of these, with a Y-like shape, is the Secretariat (1). A lower and slightly curved block (4) connects the main volume of the Secretariat with the trapezoidal Conference Building (2). At the northeastern corner of the site sits an annex, the four-story building housing the permanent delegates (3). Later, the complex was supplemented by a buried extension by Bernhard Zehrfuss. The seven-story Secretariat follows the rounded shape of the Place de Fontenoy on which it stands, and rests on 72 expressive concrete pillars. However, the most interesting piece is the trapezoidal Conference Building, regarded by Lewis Mumford as "the one structure of great architectural distinction in the group of three" (Mumford 1963, 79). The east and west walls are of folded concrete, with a surface that bears the textures of the wooden form boards and contrasts with the smooth travertine and granite of the longer sides. The building is covered with a ribbed, butterfly-shaped, reinforced concrete roof clad in copper (Fig. 5).
The Secretariat and the folded plates of the Conference Hall were built with in-situ concrete, despite the fact that Nervi was an expert at using prefabricated elements (Fig. 6). As he later explained, it made no sense to use precast concrete because the architects did not know who was going to build the concrete structures. ${ }^{3}$ Nervi held that the simplest concept is always the best and the available means have to be taken into consideration. He believed in simplicity as the best approach: as he used to say, "The obvious solution [is] the logical thing to do" (Huxtable, 1960:6). Simplicity and efficiency were always the rule. Therefore, in the folded structure for the Conference Building roof, the material is where it is most needed; the concrete slab of the roof rises where there is positive bending moment and falls when negative (Fig. 7). As Nervi stated, one never has to think in terms of economy of poverty, but in terms of essential economy. ${ }^{4}$ 

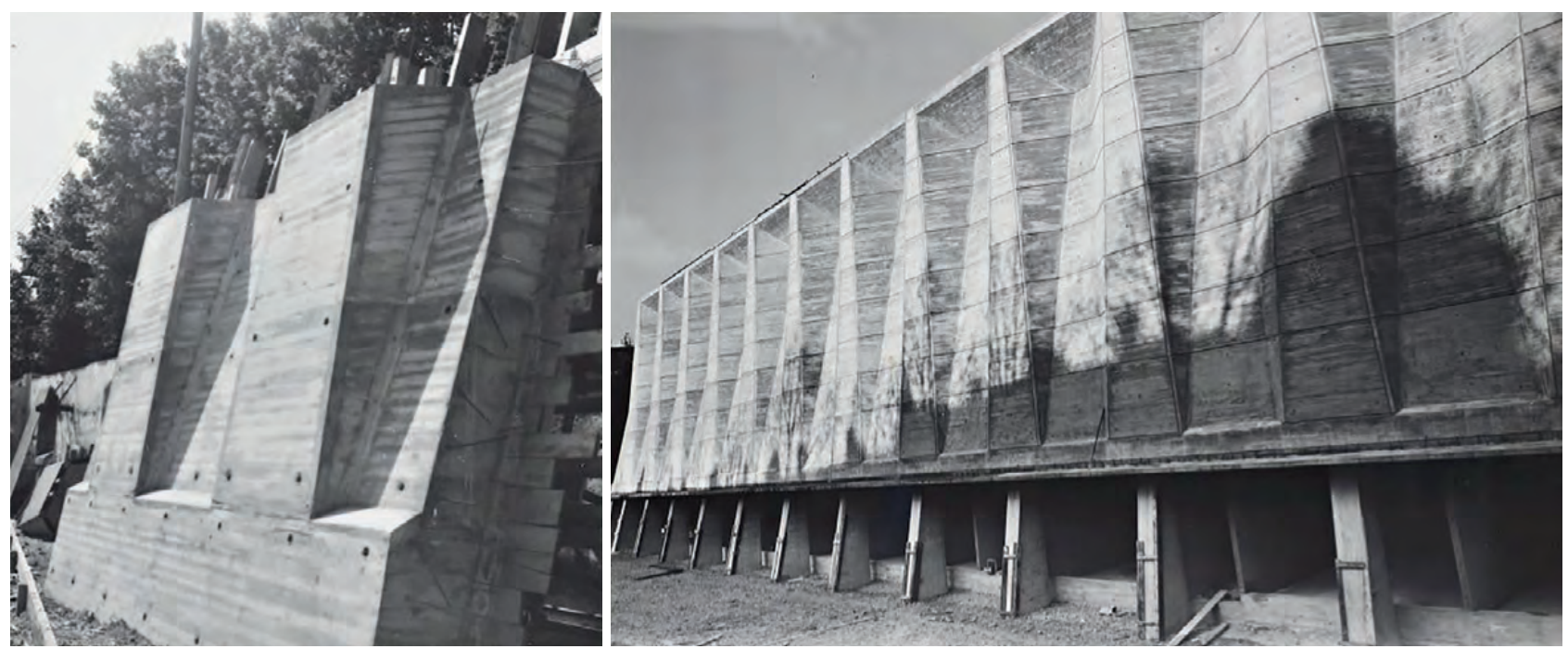

Figure 6. Folded concrete walls of the Conference Hall under construction, UNESCO Headquarters Paris. P.L Nervi, M. Breuer and B. Zehrfuss. 1955-58. L. Hervé.

On the other hand, Breuer had a completely different approach; he did not want to use the material only in the most efficient structural way, but in the most effective architectural one. Nervi was a great engineer and a talented architect, but Breuer was a master of spatial concerns. He wanted to take advantage of the properties of concrete and use it for the walls in the Conference Hall, not only in the roof as Nervi always wanted. It was important for Breuer to extend the main structural and architectural expression of the building to the vertical enclosure; for him, structure and architectural space were the same element.

Is there any particular reason why structure should be identical with the architectural form? I think there is, to a great extent. [...]As in all aspects of building, there is the natural, the logical way. [...]l feel that the structure should be expressed where possible and where it makes natural sense. (Breuer 1955, 156)

Finally, Nervi extended the main structure to the walls. The same expressive and structurally effective folded plate turned from the horizontal plane of the roof to act as a vertical background for the Conference Hall. This was the first and only example in the Italian architect's entire career in which he designed a vertical wall as a principal element of the building (Fig. 8). This fact underscores Breuer's persuasive capabilities: he was able to convince Nervi to do something the latter had never done and would never dare to do again.
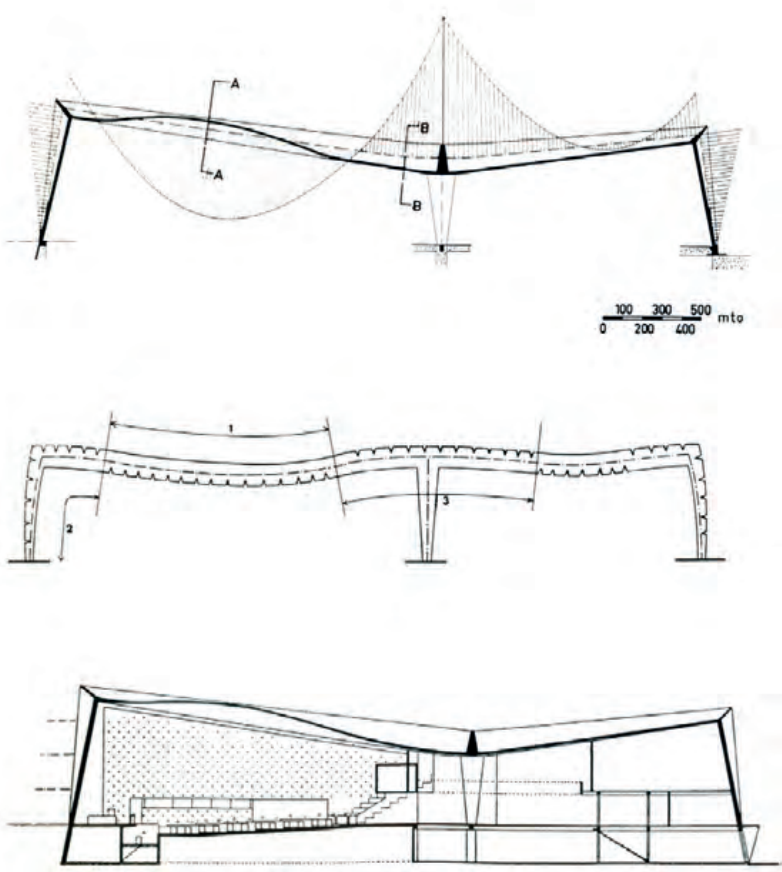

Figure 7. Conference Hall: Bending moment diagram, deflection diagram and longitudinal section. UNESCO Headquarters. P.L Nervi, M. Breuer and B. Zehrfuss. 1955-58. 


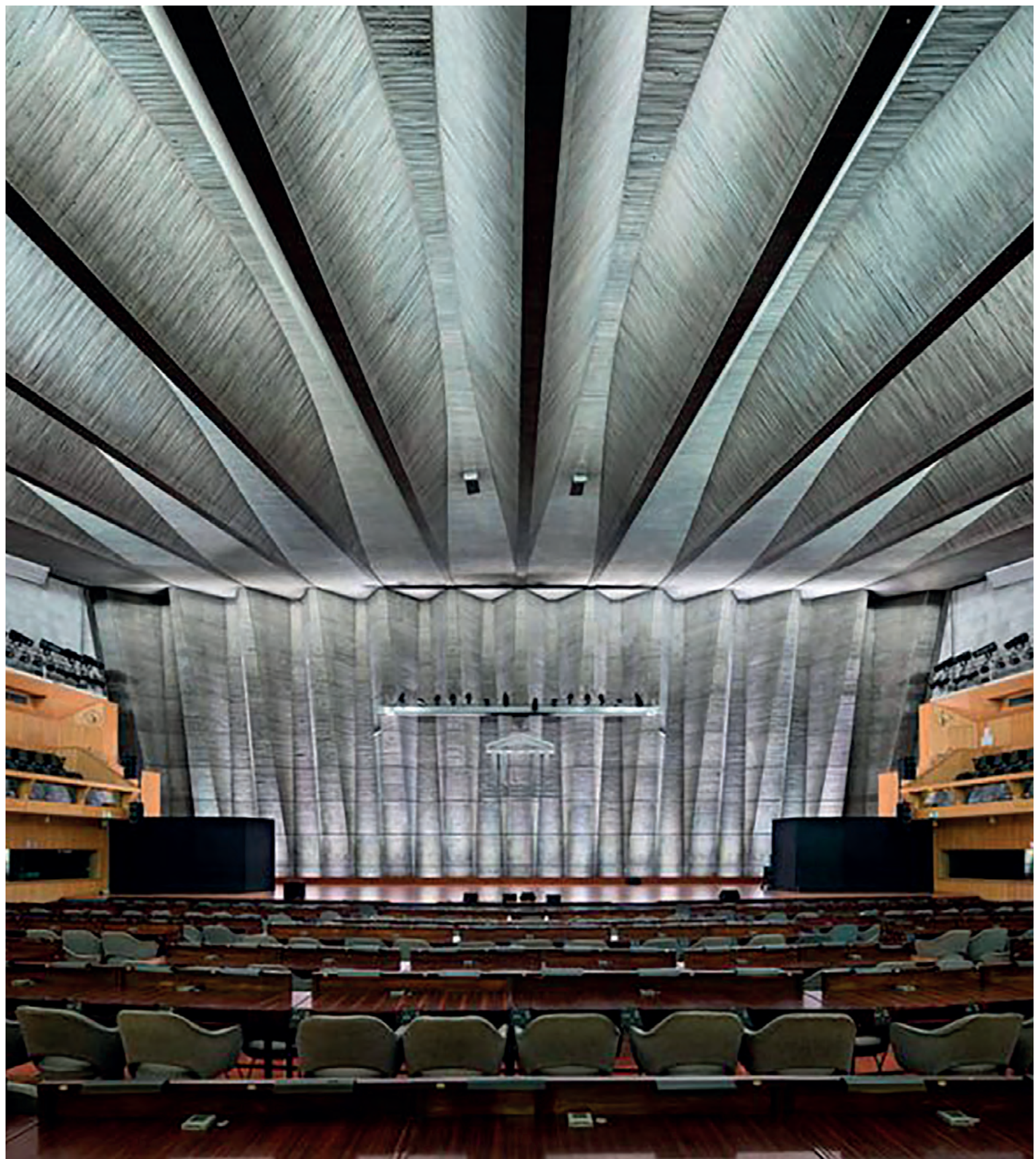

Figure 8. Interior view of the Conference Hall. UNESCO Headquarters. P.L Nervi, M. Breuer and B. Zehrfuss. 1955-58. B. Zehrfuss. 


\section{Breuer and the new material}

The Conference Building in the UNESCO complex entails a milestone in Nervi's work, but the one really affected by this project was Breuer, for whom the complex represented a turning point in his career. While involved in the project, he published the book: Marcel Breuer: Sun and Shadow (1955), edited by Peter Blake, where he explained his philosophy and the way he understood and conceived architecture. In the book, the experience and the influence he was gathering in Paris started to become evident. So far, Breuer had mainly built small residential buildings out of wood and stone, but in the third of the book's four parts, he wrote the following, in relation to structures:

Until very recently, the only way to build was to exploit the weight of stones or bricks or wooden logs, to pile on top of the other, each holding down the one below as well as itself, and to span short distances with beams or arches that depended upon the same gravity or compression-principle for their strength.

The great change in construction over the past few decades has been the shift from simple compression structures to continuous, fluent tension-structures. This change is so radical that it alone would justify a completely new architectural expression.

What has happened is that several new materials with great tensile strength, like steel, reinforced concrete and, more recently, some alloys of aluminum, have been developed. (Breuer 1955, 180)

It is obvious that being in contact with Pier Luigi Nervi deeply impressed Breuer, providing an important influence in relation to construction systems. Breuer, who had shown an interest in concrete before, renewed his fascination with the powerful material:

The most interesting developments in structural design are those using reinforced concrete. Here is a completely plastic medium. ... For here the material not only acts as the support of the building, but also as the enclosure, the form. Not only bones alone, but bones, muscles and skin combined.

A great deal of experimentation with reinforced concrete has been carried on in Europe and South America. This way of building requires a great deal of work on the building site-it means high cost in countries like the United States where site labor is expensive. But many of those new, continuous reinforced concrete structures have been made up of hundreds of prefabricated parts that are lifted up into position and connected to the next part. As we get more of this development in America, I believe we will see more

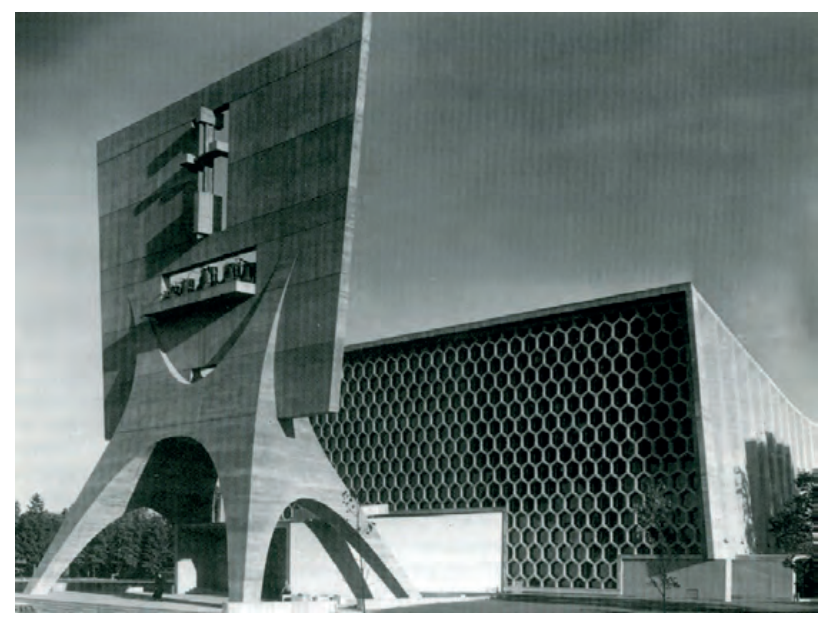

Figure 9. Church and Campanile at Saint John's Abbey in Collegeville. Marcel Breuer. 1961. L. A. Hanley.

of these exciting new structures and they will become economically feasible here also. (Breuer 1955, 181)

These words, published while the project for the UNESCO headquarters was still ongoing, revealed that Breuer did not foresee widespread use of concrete in the United States in the near future, but seemed openly interested and at the same time positive about a possible long-term future for precast concrete. He actually proved wrong himself one year later when introducing in-situ concrete in the church for the Saint John's Abbey in Collegeville, Minnesota (Fig. 9). The church has a close relationship with the Conference Building in the UNESCO Headquarters, showing the large impact the Parisian experience had on him. The overall trapezoidal shape and the folded concrete plate for the structure have a direct connection with the Parisian building. Correspondence with Breuer's employees in New York while Breuer while working in Paris (Fig. 10) proves this connection:

I thought you would be interested to see the enclosed three enlarged snapshots of the UNESCO Headquarters under construction. [...]The wide spanned structure with the folded end walls and roof system would I believe be of interest to you for the expression they convey. The photos may also help you to visualize our church project. (Marcel Breuer Digital Archive. University of Syracuse, 2015)

The church was both his very first big solo commission and first concrete building in the United States, which laid the path to a prolific and successful career, a career that never again veered from 


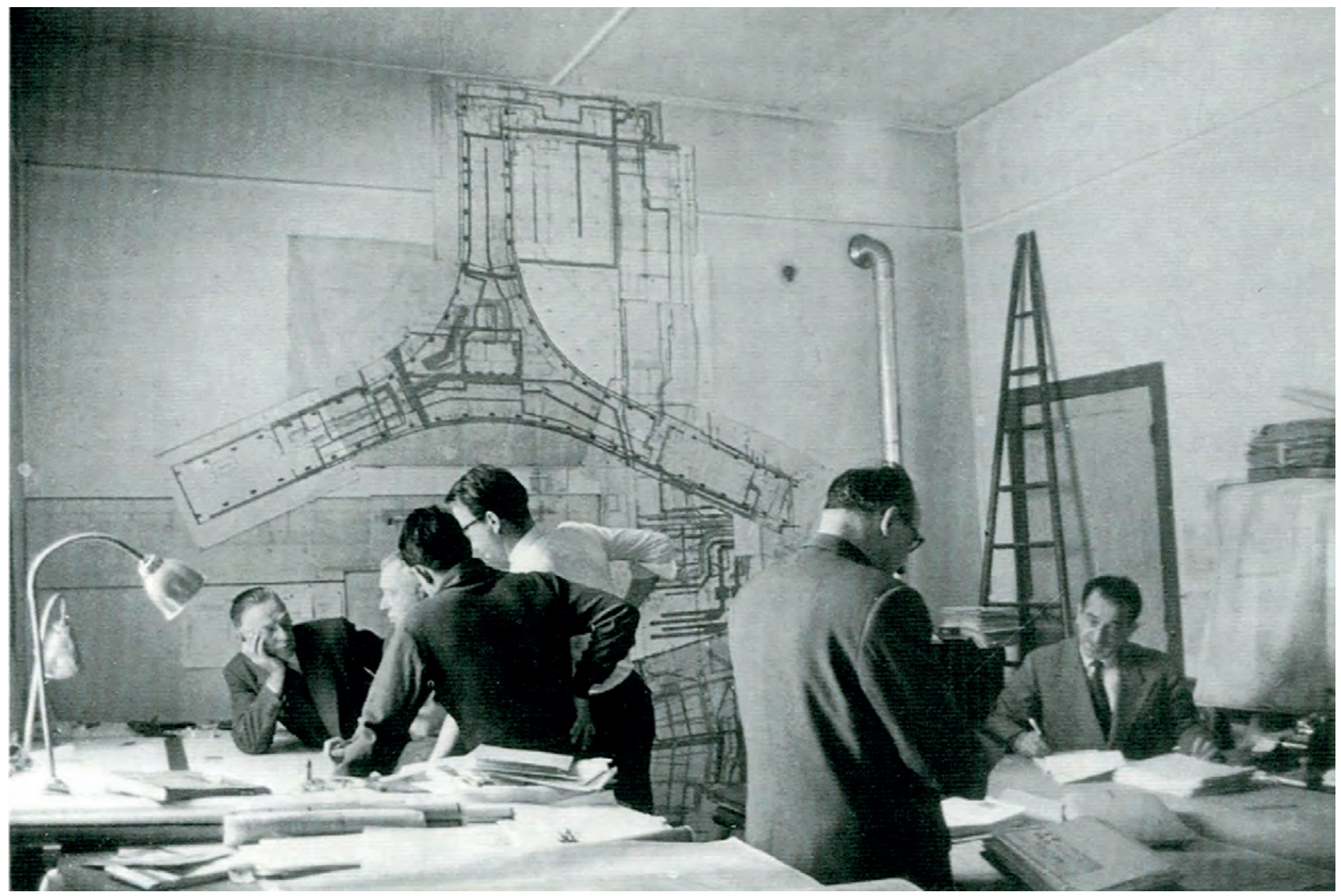

Figure 10. Marcel Breuer and Associates, Paris. Ralph Lieberman

that material. For Breuer, concrete was the material that allowed him to express and achieve his aesthetic interests because it "follows more readily than any other material the imagination of the designer. No material has more potential [...] [It] allows the architect three dimensions; he can design elevations moving in and out, he can create depth in a façade, he can become master in a new baroque" (Breuer 1973). In the UNESCO project, Marcel Breuer started a relationship with concrete that would guide his career until its very end. As he said to Winthrop Sargeant:

I like to use concrete because it has a kind of rugged quality. It is not a sweet material. It is a relief in modern architecture from all that glass and steel. Also concrete can do almost anything in a building. It represents both structure and enclosure and per consequence it expresses structure more directly than any other material. (Breuer ca. 1971-72)

\section{Bizarre Love Triangle}

The UNESCO Headquarters in Paris is a remarkable example of architecture of the $20^{\text {th }}$ century. It is remarkable not only due to its undeniable architectural qualities, but also because of the historic collaboration between Pier Luigi Nervi and Marcel Breuer ${ }^{5}$. What is more, the UNESCO building represented a turning point in each of their careers. On the one hand, Breuer was introduced to concrete, the material he would never abandon; on the other, Nervi designed for the first time a relevant structural element in the shape of a wall, fully exploring the structural and architectural qualities of concrete. 
These rather simple, but relevant facts are a clear reflection of what great professionals both architects were. Breuer and Nervi influenced each other to the point of breaking their long-established modus operandi and reaching a level of architectural quality neither had yet achieved in their work. With the UNESCO project, their careers and the way they understood and approached architecture crossed in a kind of bizarre love triangle. Inside the walls of the Conference Building, the two architects underwent a radical change. The only difference is that while Nervi only had a little affair with the structural vertical plane, Breuer found in concrete the love of his life.

\section{Bibliographic references}

- Abram, J. 2010. "Pier Luigi Nervi: Strength through Form, Form as Structure". In Pie Luigi Nervi: Architecture as Challenge, edited by OImo, C. and Chiorino, C. Milan: Silvana Editoriale.

- $\quad$ Argan, G.C. 1955. Pier Luigi Nervi. Milano: II Balcone.

- Breuer, M. 1955. Sun and Shadow, the Philosophy of an Architect. Edited by Peter Blake. New York: Dodd, Mead and Company.

- Breuer, M. and Jones, C. 1962. Marcel Breuer: Buildings and Projects 1921-1961. New York : Praeger, - Books that matter.

- Breuer, M. ca 1971-72. "Profile of Marcel Breuer", Quoted in a manuscript draft prepared for the New Yorker by Winthorp Sargeant

- Breuer, M. 1973. Interview for Schokbeton, Trade publication of Shokbeton Products.

- Fernández Ordóñez, J.A. 1978. Eugène Freyssinet 1879-1962. Barcelona:v2C Editions.

- Harvard University. n.d. Breuer, Marcel, 1902-1981. The Breuer Lectures Collection: An Inventory. Accessed December 1, 2017, http://oasis.lib.harvard.edu/oasis/deliver/ des00023

- Herman, A. 1959. Formes Utiles. Paris: Edition du Salon des Arts Ménagers

- Huxtable, A.L. 1960. Pier Luigi Nervi. Pampoa Press.

- Hyman, Isabelle. 2001. Marcel Breuer Architect. The Career and the Buildings. New York.

- Lagorio, I. and Lagorio, H. 1961. Pier Luigi Nervi: Space and Structural Integrity. s.I.: Associated Arts Foundation.

- Le Ricolais, R. 1962. "Entretiueri avec Michel Ragon", ins Arts, 30 May 1962; republished in Écrits d'oingenieurs by Bernard Marrey. 1997. Paris: Editions du Linteau.

- Marcel Breuer Digital Archive. University of Syracuse. 2015. Correspondence: Breuer to Dworschak, July 30, 1956. Accessed May 13, 2016

- Mumford, L. 1963. "Unesco House: The Hidden Treasure", The Highway and the City. New York: Harcourt, Brace and World

- Nervi, P.L. 1956. Structures. New York: McGraw-Hill Book Co

- Pearson, C. 2016. Designing UNESCO: Art, Architecture and International Politics at Mid-Century. Routledge.

- Unesco. n.d. "Three Architects, Three Nationalities", Accessed November 13, 2017 http://www.unesco.org/new/en/unesco/about-us/who-we-are/history/architects/
Javier Martin is Professor for Design and Construction at the BAU International Berlin University of Applied Sciences, where he is also Head of the Interior Design Program. He has previously taught at various universities in Chile, including the Catholic University and the University of Chile.

Prof. Martin is an architect, having graduated from the Polytechnic University of Valencia, Spain. He holds a Masters in Design Studies (Technology) from the Harvard University Graduate School of Design, where he also worked as a Teaching Assistant and collaborated with the Wyss Institute for Biologically Inspired Materials. Prof. Martin's research revolves around the fields of materiality, technology and tectonics. His research has been widely published and presented in different congresses as the symposiums of the International Association for Shell and Spatial Structures.

Prof. Martin has worked for Zvi Hecker in Berlin, and his own independent work has been internationally awarded and published, and exhibited extensively, including at the Museum of Modern Art in New York City.

Notes

1 The collection was created in 1997 with the information coming from the gift of a GSD alumnus (Harvard University Library n.d.).

2 In the folder A0017, there is one manuscript sheet by Breuer that may be related to the Breuer typescript Speech on the Occasion of the Exhibit of Pier Luigi Nervi's Work at the Architectural League, 1959, held by the Smithsonian Archives of American Art (Harvard University Library n.d.).

3 Notes taken by a student at the lectures of Pier Luigi Nervi at the University of Rome during the school year 1959-60.

4 Ibid. P.L. Nervi did not merely aim to spend the minimum amount of resources on a project, but to use the budget in an efficient and rational way; he did not aim for the least expense, but to get the best out of what was available.

${ }^{5}$ Not to forget the important participation of the French architect Bernard Zehrfuss. 